\title{
作物における光合成産物転流の経路と機構
}

長南信雄 ${ }^{*}$

\begin{abstract}
緑葉中での光合成の機構については膨大な研究があり，さまざあな解説も書かれている. しかし，我々が作 物として利用する果実・種子や根中に貯蔵されるそれら産物は, どのような経路で, どのような変化を受け つつ移動してゆくのであろうか. この古くて新しい重要な問題を組織・細胞化学的観点から捉えると……
\end{abstract}

最近の光合成に関する研究の発展はめざましい ものがあり, 高い光合成能力と結びついた $\mathrm{C}_{4}$ ジ カルボン酸経路の発見は，イネやュムギなど $\mathrm{C}_{3}$ 型作物の生産力向上に新たな展望を与えるものと して注目されている. しかし, 光合成産物の転流 または蓄積の過程が何らかの要因で抑制される と，光合成自体も抑制されることが明らかになっ てきた.このことは, 光合成をはじめ転流および 蓄積にいたる一連の過程がすべて効率よく進むこ とによってはじめて作物の高い生産力が発揮され ることを示している.

光合成は主として葉緑体をもつ葉肉細胞内で行 なわれ, 光合成産物は果実・種子などの貯蔵器官 や生長中の若い組織へ送られる. 一般に, 光合成 産物の供給体をソース (source) と呼び, その受 容体をシンク（sink）と呼んでいる. ソースから シンクヘの光合成産物の転流経路の一例を模式的 に示したのが図1である.この図は，イネの葉身 から葉鞘のデンプン貯蔵細胞（基本柔細胞）に光 合成産物が転流して，貯蔵される場合について示 したものである。これによれば，光合成産物はま ず葉肉細胞から最寄りの葉脈（維管束）内の師管 に入る. 師管の周囲には数個の柔細胞が存在し, さらにその周囲を葉緑鞘やメストム鞘と呼ばれる 維管束鞘の細胞がとり囲んでいる.したがって， 光合成産物が師管に到達するまでには, 数個の細 胞間を移動しなければならない。このような転流 はソース内短距離転流と呼ばれる.

維管束の師管に入った光合成産物は, 葉から茎

* Nobuo CHONAN, 茨城大学農学部
を通って果実・種子あるいは根端や茎の生長点な どに $50 \sim 100 \mathrm{~cm} / \mathrm{h}$ の速度で転流するので, 長距 離転流と呼ばれている. 長距離転流の途中で, 光

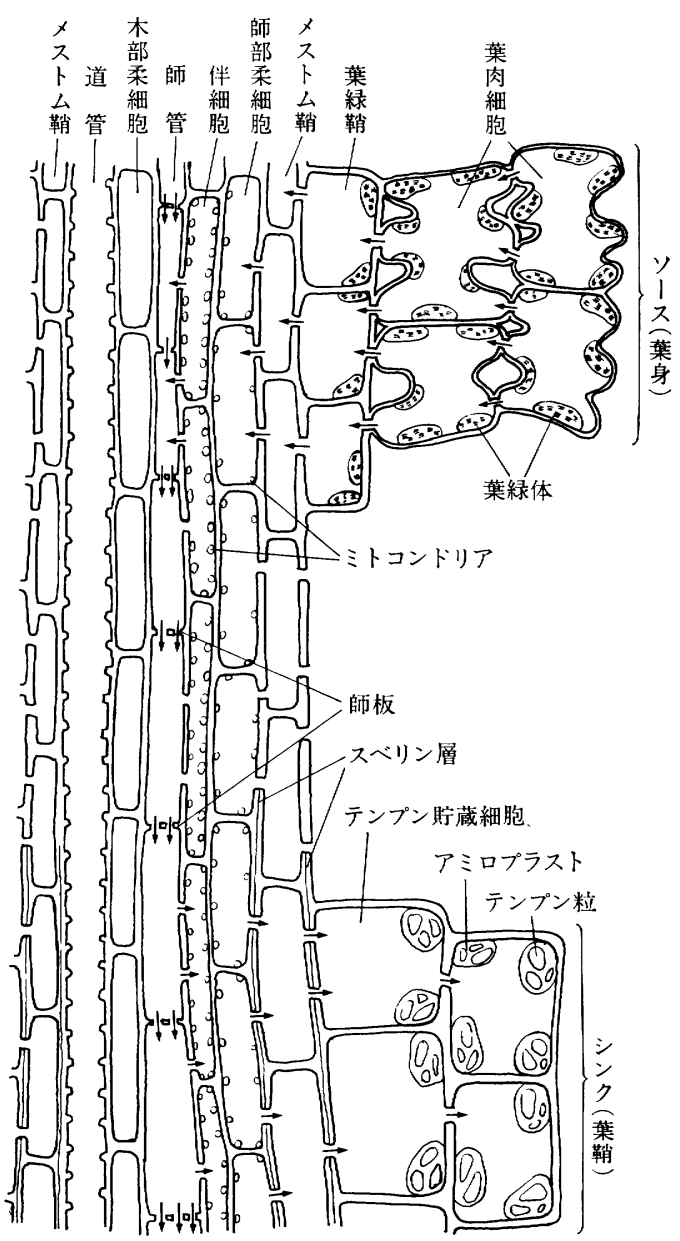

図 1 ソースからシンクヘの光合成産物の転流経路 模式図 矢印はシンプラスト経路を示す. 


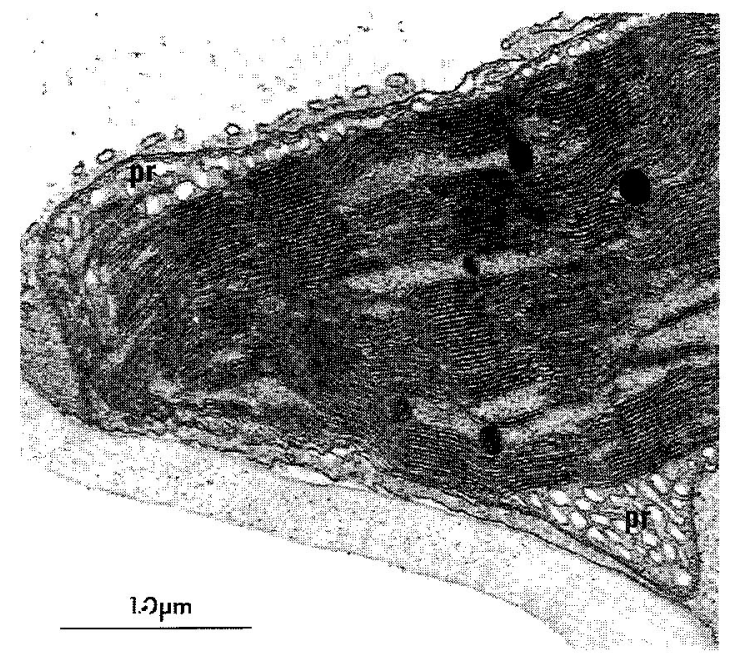

図 2 シコクビエ $\left(\mathbf{C}_{4}\right.$ 植物) の葉緑体 (長南涪図)

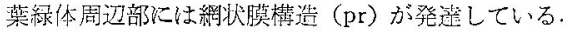

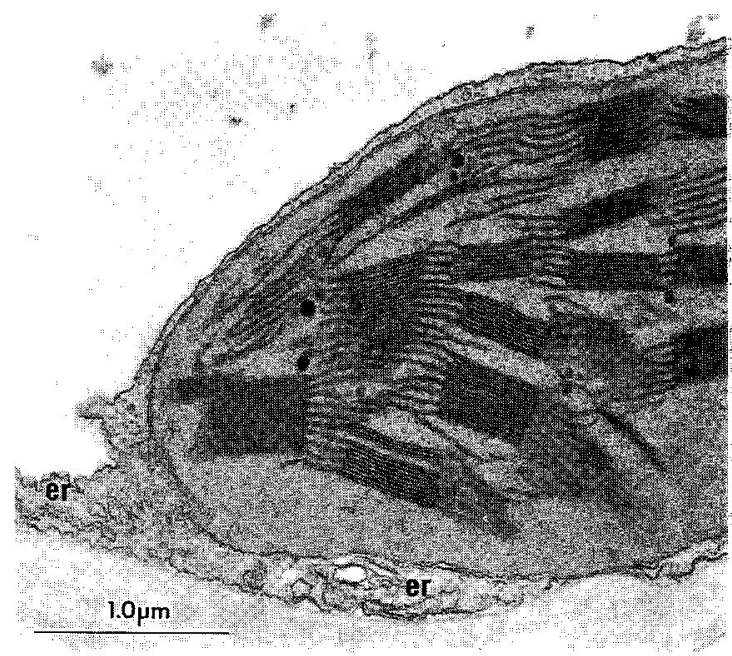

図 3 トールフェスク $\left(\mathbf{C}_{3}\right.$ 植物) の葉緑体 (長南原図) er：小胞体

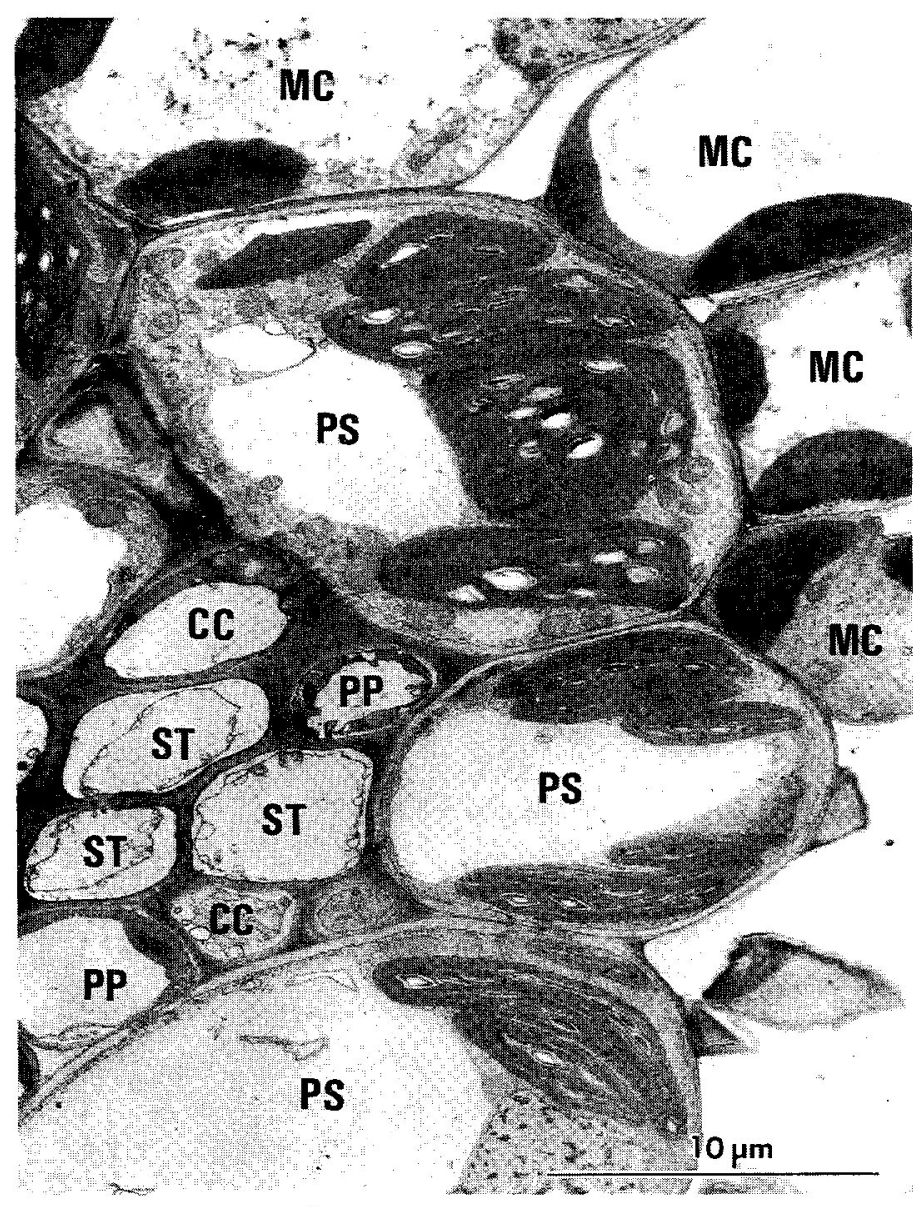

図 4 トウモロコシ $\left(\mathbf{C}_{4}\right.$ 植物) 葉身の維管束横断面の一部 (屒南原図)

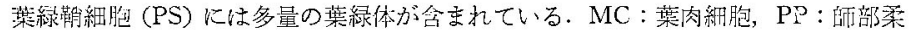
細胞, ST : 師管, CC : 伴細胞. 


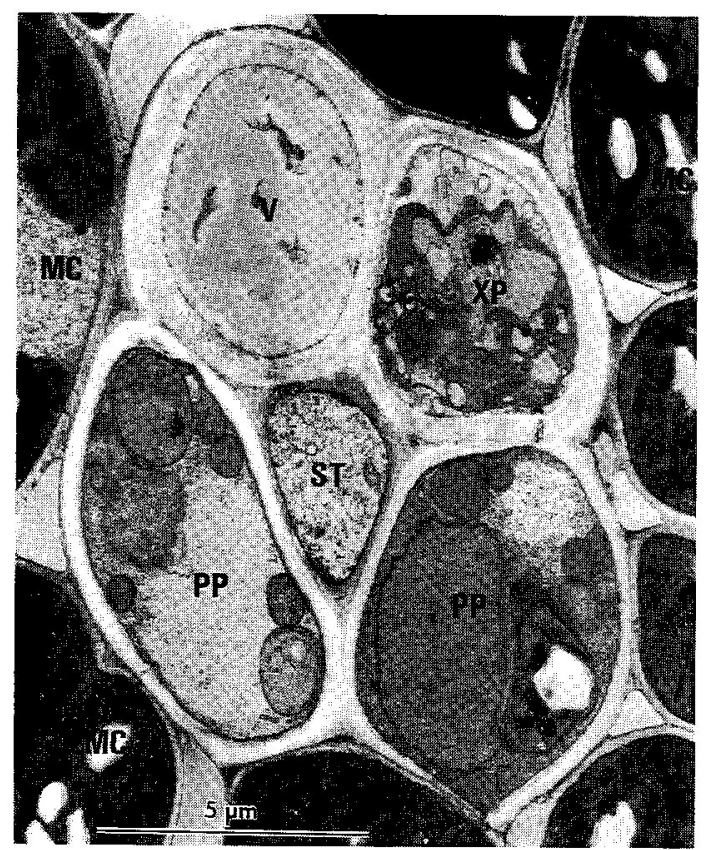

図 5 イネ $\left(\mathrm{C}_{3}\right.$ 植物)葉身の横走維管束断面 ${ }^{(13)}$ MC : 贤肉細胞, PP : 師部柔細胞, ST : 師管, V : 道管, $\mathrm{XP}:$ 木部柔細胞

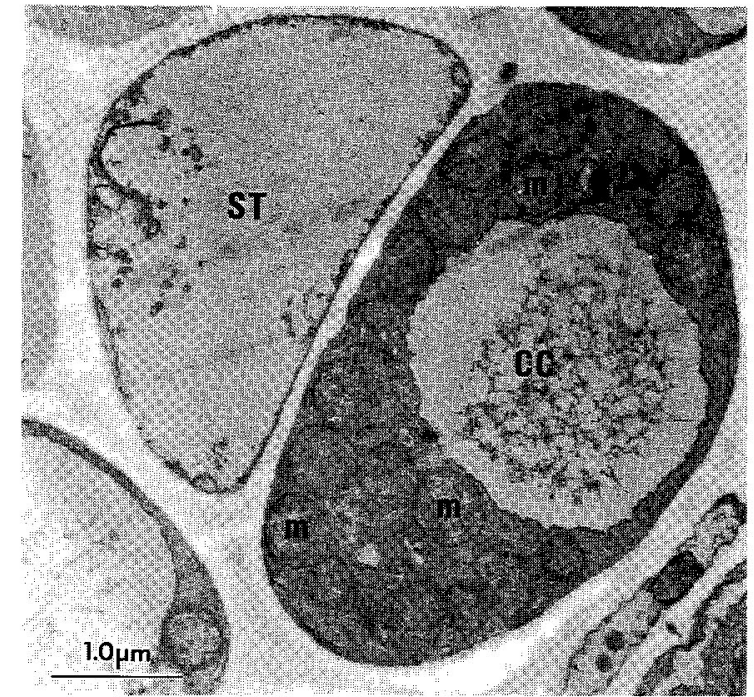

図 6 イネ葉身維管束の師管・伴細胞複合体(長献原図) 伴細胞 (CC) には多数のミトュンドリア (m) が含まれてい る. ST : 師管

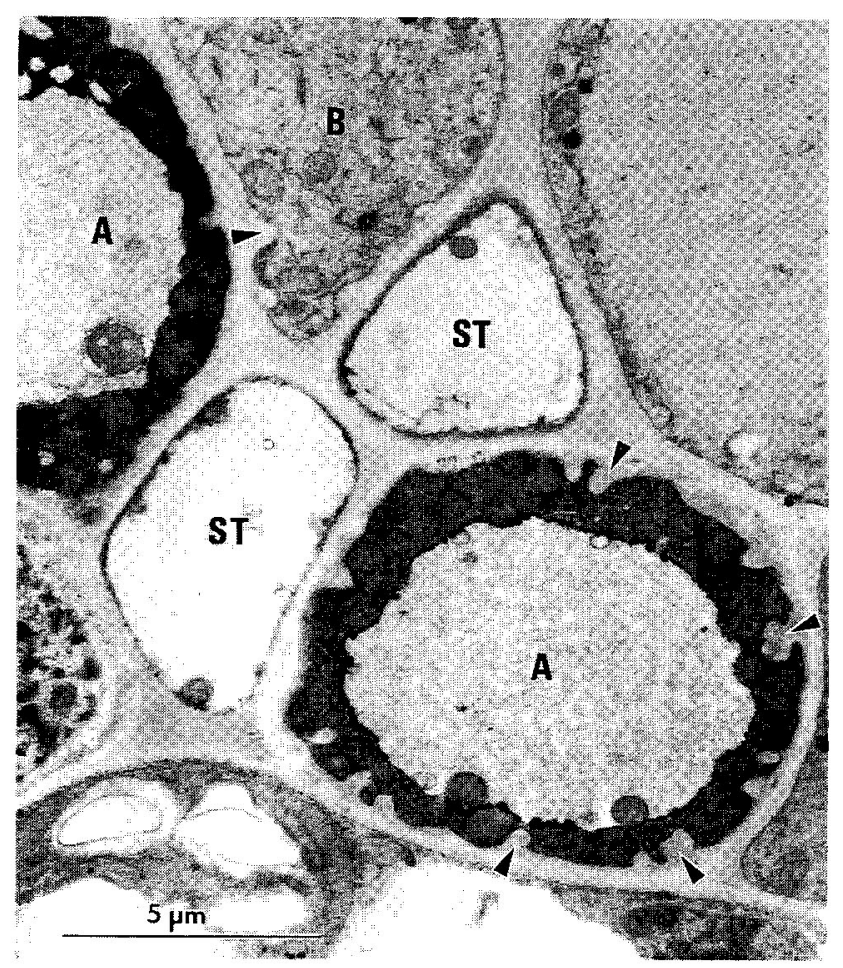

図 7 エンドウ葉身の師部転送細胞をもつ維管束 ${ }^{(3)}$

$\mathrm{A} ： \mathrm{~A}$ 型師部轱淡細胞， B：B型師部䎐送細胞， $\mathrm{ST}$ ：師管，矢印は細胞 壁突起を示す。. 


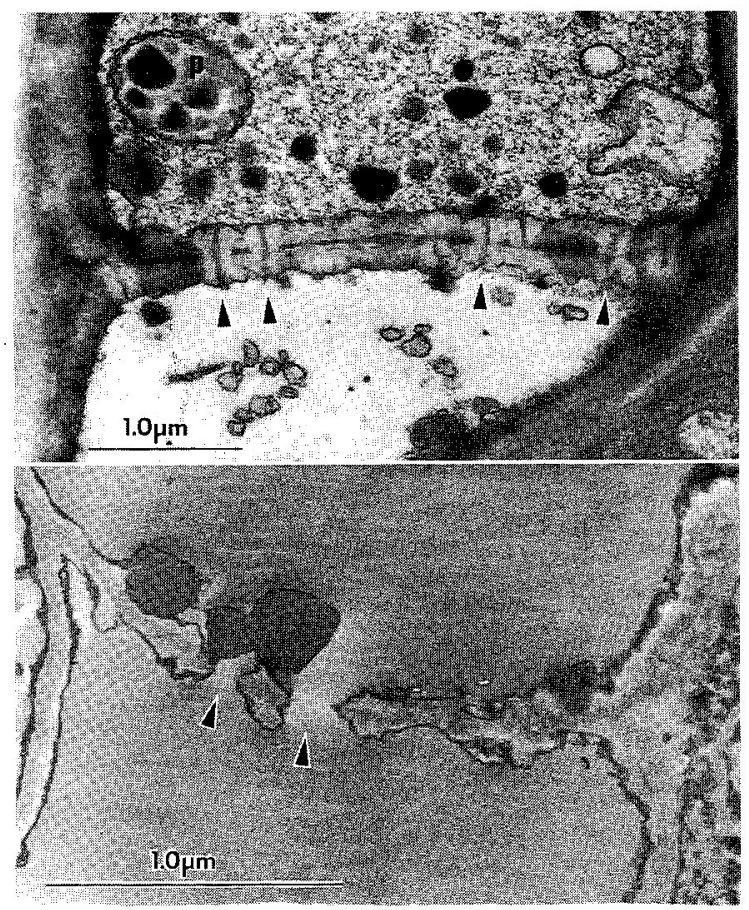

图 8 イネの師板断面（上：長南原図，下：川原ら ${ }^{(11)}$ ) 上：グルタールアルデヒドとオスミック酸炕よる固定，耐孔（失印）はカロー

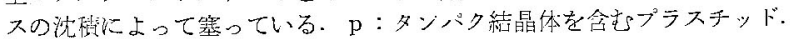

下：谏結置換法による. 師孔（矢印）は開いている。

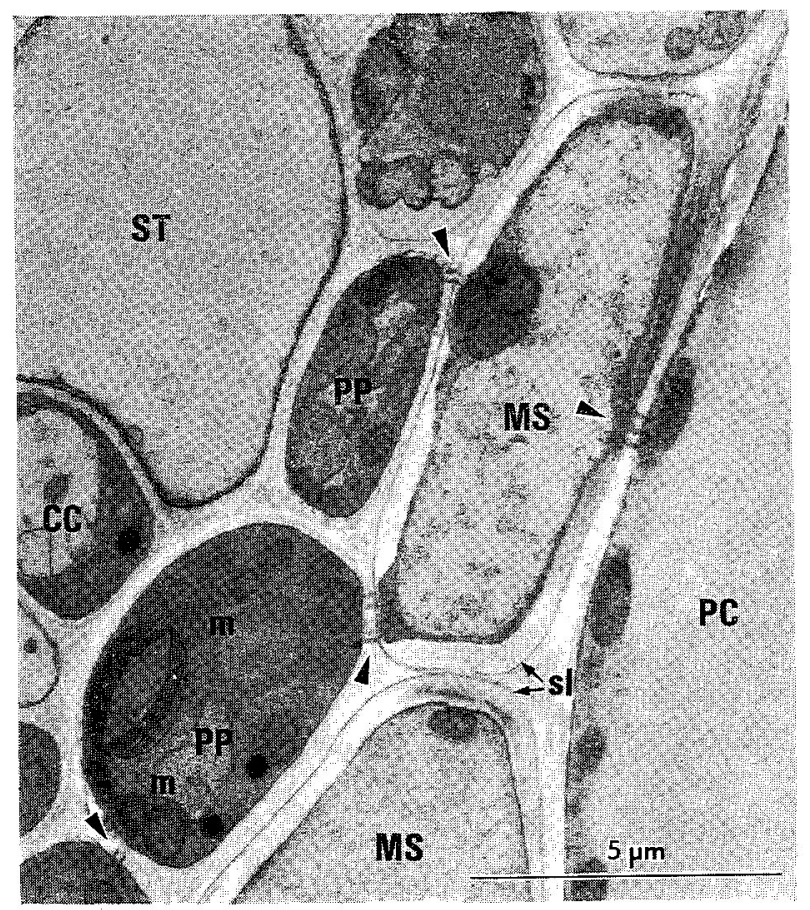

図 9 イネ葉鞘の維管束横断面の一部 ${ }^{(12)}$

$\mathrm{ST}$ : 師筸, $\mathrm{CC}$ : 伴細胞, PP : 師部柔細胞, MS : メストム䩼細胞, PC : デ

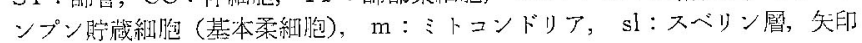
蛙原形留连絡定示す。 
合成産物の一部は葉鞘や茎などの基本柔細胞に一 時的に貯蔵されるが，稔実期にはこれらの貯蔵物 質は葉からの光合成産物とともに果実・種子に転 流寸る. 貯蔵器官に達した光合成産物は, 師管か ら出て再び細胞から細胞へと移動するので，この 転流はシンク内短距離転流と呼ぶことができる.

このように，光合成産物の転流過程はソースお よびシンク内の短距離転流と長距離転流に分けら れる. 以下，これら転流の経路とその機構を主と 乙て組織・細胞学的知見に基ついて考えてみたい。

\section{葉緑体と葉肉細胞の転流系構造 $(4,9,10)$}

光合成初期産物は，葉緑体の包膜を通過して細 胞質に出る. 内外 2 枚の包膜のうち内膜が選択的 透過性をもち，外膜はあまり物質透過の障害には ならない.トリオースリン酸（DHAP）は包膜を 透過し易く, $\mathrm{C}_{3}$ 植物ではこの物質から細胞質内で スクロースが合成される，一方， $\mathrm{C}_{4}$ 植物では， 葉肉細胞の葉緑体でリンゴ酸やアスパラギン酸な ぞの $\mathrm{C}_{4}$ ジカルボン酸が合成され，これらの光合 成初期産物が容易に包膜を透過して細胞質に流出 する.

$\mathrm{C}_{4}$ 植物の葉肉細胞内葉緑体（図 2）では，内 膜系が周辺部までよく発達し, 包膜のすぐ内側に は網状の膜構造（peripheral reticulum, pr) が 発達している. この膜構造は, 内部のチラコイド 膜に連絡すると同時に，包膜の内膜にも連絡して いる. この網状の膜構造によって葉緑体内部と包 膜の接触面積が著しく抎大され，光合成初期産物 の細胞質への輸送が促進される. 一方, $\mathrm{C}_{3}$ 植物 の葉緑体（図 3）には周辺部の網状膜構造が臣と んど発達せず，包膜の内側はストロマによって占 められている.

光合成産物は, 細胞質内対流にのって移動する 過程で小胞体（er）にとり込まれ（図 3)，各種酵 素から隔離される. 光合成産物が隣接する葉肉細 胞に移動する場合は，原形質連絡を通る．原形質 連絡は細胞壁を貫通する微小な管で，その直径は 約 $60 \mathrm{~nm}$ である. 原形質連絡は二重の管から成 り，外側の管は隣接する両細胞の原形質膜に連絡 し，内側の管は小胞体に連絡している. したがっ
て，光合成産物が葉肉細胞間を移動する場合は, 小胞体 $\rightarrow$ 原形質連絡 $\rightarrow$ 小胞体という経路を通るこ とになる．原形質連絡には ATPase が検出され ることから，括約筋のような働きによって，光合 成産物を積極的に流しているといら考光もある が，原形質連絡の総断面積と転流量から転流速度 を計算した結果によると，原形質連絡の両端に生 ずる光合成産物の濃度勾配によって拡散するとい ら説が有力である.

葉肉細胞は光合成反応に必要な $\mathrm{CO}_{2}$ を吸収す るために, 細胞間隙に露出する表面積をできるだ け大きくするような形をとっているが，このこと は必然的に隣接細胞との接触面積を小さくし，原 形質連絡による光合成産物の移動にとって不利な 結果を招くことになる，高等植物の葉肉組織は, 種によってそれぞれ特有な細胞の形と配列をとる ことにより，この矛盾を解決している。たとえ ば，双子葉植物の葉の表側には円筒状の柵状細胞 が葉の表面に対して直角の方向に配列し，柵状細 胞の相互連絡はみられないが，葉肉組織の内層部 で海綿状細胞と連絡している．一方，海綿状細胞 は相互に連絡し，維管束に光合成産物を輸送する 通路となっている。また，イネ科植物の葉肉細胞 は，数個の突起をもった有腕状の形を示し，細胞 表面積を拡大するとともに突起の先端部で隣接細 胞と原形質連絡によって連絡している（図 1).

\section{維管束鞘細胞の構造と機能}

葉肉細胞でつくられた光合成産物は, 維管束を とり巻く維管束鞘細胞を経由して師部に送られ る. 維管束鞘細胞ではスクロースやデンプンの合 成をはじめ，光合成産物を葉緑体や液胞の中に一 時的に 貯蔵して 細胞質内の 糖濃度を調節するな ぞ，さまざまな機能を果たしているものと考えら れる. 維管束鞘細胞は葉緑体をもつ葉緑䩗細胞と それをもたないメストム鞘細胞の 2 種類に分けら れるが，植物の種類や器官の種類によってそのい ずれかを欠く場合がある.

\section{1. 葉緑鞘細胞 ${ }^{(8,9)}$}

一般に, 葉の維管束の周囲には葉緑鞘が存在す 
るが，その機能は $\mathrm{C}_{3}$ 植物と $\mathrm{C}_{4}$ 植物で異なる. $\mathrm{C}_{4}$ 植物の葉では葉緑鞘細胞がよく発達し, 葉肉 細胞内の葉緑体とは構造の異なる葉緑体を多量に もつ(図 4). この葉緑鞘細胞は葉身の断面では花 冠のよらに見えることから，クランッ(Kranz) 細 胞とも呼ばれている. $\mathrm{C}_{4}$ 植物の葉肉細胞でつく られた $\mathrm{C}_{4}$ ジカルボン酸は葉緑鞘細胞に移動し, 脱炭酸反応により $\mathrm{CO}_{2}$ とピルビン酸になる.こ の反応により葉緑鞘細胞内の $\mathrm{CO}_{2}$ 濃度が著しく 高まり，カルビンーベンソン回路によるスクロー ス合成が促進される．このように， $\mathrm{C}_{4}$ 植物では スクロース合成が維管束のすぐ外側をとり巻く葉 緑鞘細胞で行なわれることによって，光合成産物 の短距離転流が効率よく進むものとみられる.

一方, $\mathrm{C}_{3}$ 植物の葉緑鞘細胞内には葉緑体が少 なく, その構造と機能も葉肉細胞の葉緑体と同じ である. すなわち， $\mathrm{C}_{3}$ 植物では葉肉細胞と葉緑 鞘細胞にカルビンーベンソン回路が存在し，この 両細胞でスクロースの合成が行なわれる。葉肉細 胞から葉緑䩗細胞まで, $\mathrm{C}_{4}$ 植物では $\mathrm{C}_{4}$ ジカルボ ン酸の形で転流するのに対して， $\mathrm{C}_{3}$ 植物ではス クロースの形で転流することになる．さらに， $\mathrm{C}_{4}$ 植物では葉緑䩗をとり巻く葉肉細胞はほぼ 1 層で あるが， $\mathrm{C}_{3}$ 植物では葉緑鞘の周囲に数層の葉肉 細胞が配列している.このため, $\mathrm{C}_{3}$ 植物の 1 個 の葉緑鞘細胞にかかる転流上の負担は $\mathrm{C}_{4}$ 植物よ りも大きい.

前にも述べたように，葉肉細胞間のスクロース の移動は, 濃度勾配に沿って拡散により原形質連 絡を通るものとみられる. 葉肉細胞から葉緑鞘細 胞への移動もやはり原形質連絡による移動である が，この両細胞間にはスクロースの濃度勾配が生 じないと移動は起こらない. $\mathrm{C}_{3}$ 植物の葉緑䩗細 胞内葉緑体には光合成産物がデンプンとして一時 的に貯蔵され，またこの細胞の大きな液胞内にも 可溶性糖類が一時的に貯蔵されることによって, 細胞質内の糖濃度が低く保たれるように調節され ているものと考兄られる. 光合成によるスクロー スの生産が葉緑鞘細胞の濃度調節能力を上まわる と, 葉肉細胞内葉緑体にもデンプンが一時的に蓄 積される.

\section{2. 細胞壁内スベリン層の役割( ${ }^{(8,9)}$}

イネ科の $\mathrm{C}_{3}$ 植物の全部と $\mathrm{C}_{4}$ 植物の一部の種 には, 葉緑鞘の内側にメストム鞘と呼ばれるもう 1 層の細胞層が発達している. メストム鞘細胞は 葉緑鞘細胞に比べて細胞壁が厚く, 葉緑体の代り にプラスチッドが含まれている、メストム鞘の細 胞壁にはしばしばスベリン層が形成される，この スベリン層は不透水性を示すので，道管を流れる 水が維管束の周囲に漏孔出るのを防ぐ役割を果た している.イネの葉鞘や節間の維管束では，スべ リン層をもったメストム鞘細胞が発達しているた めに、蒸散流を効率よく葉身に流すことができる (図 1,9).

メストム鞘の細胞壁にスベリン層が発達してい ても，原形質連絡はこのスベリン層を貫通してい るので光合成産物の移動の妨げにはならない.と くに, 葉が展開してから最も活発に転流機能を果 たす後生師部の外側に位置するメストム鞘の細胞 壁には，原形質連絡が密集しているので，スクロ 一スはこの通路によって師部柔細胞に流入する.

師部柔細胞に流入したスクロースは，後に述べる ように原形質膜を通過してフリースペース（細胞 壁内扣よび原形質膜と細胞壁の間）に放出される が，メストム鞘細胞壁のスベリン層はフリースペ 一スのスクロースを維管束の外側に逆流しないよ う封じ込める働きもしている.

$\mathrm{C}_{4}$ 植物のある種の葉身では, 維管束が 葉緑鞘 細胞のみによって囲まれていて，その細胞壁には スベリン層が発達している（図 4). 葉肉細胞で つくられた $\mathrm{C}_{4}$ ジカルボン酸は，スベリン層を貫 通する原形質連絡を通って葉緑鞘細胞に入り, 脱 炭酸により $\mathrm{CO}_{2}$ 濃度が著しく高まるが，スベリ ン層はこの $\mathrm{CO}_{2}$ を細胞内に封じ込める働きもし ている.

\section{師部内のアポプラスト経路 ${ }^{(5,10)}$}

光合成産物が葉肉細胞から維管束鞘細胞を通っ て師部に入るまでの転流経路は, 細胞間の原形質 連絡による移動である.すなわち，原形質膜の内 側で物質の移動が行なわれるので, シンプラスト 経路と呼ぶことができる. しかし，光合成産物が 
師部柔細胞を経由して師管に入るまでの過程では フリースペース，すなわち原形質膜の外側のアポ プラスト経路を通ることが明らかになってきた.

また，このような師部内の短距離移動経路につい ては， $\mathrm{C}_{3}$ 植物と $\mathrm{C}_{4}$ 植物の間で基本的な差異はみ られない。

光合成産物の 細胞間移動経路を調べるために は， ${ }^{14} \mathrm{C}$ をトレーサーとしたミクロオートラジオ

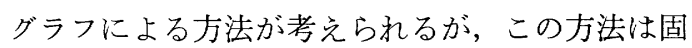
定, 包埋など顕微鏡観察のための材料処理過程で ${ }^{14} \mathrm{C}$ が移動する危険性がある，そこで，間接的に 光合成産物の移動経路を知る方法として, 原形質 連絡の 細胞間の分布を 調べる方法がとられてい る. 細胞間に原形質連絡が存在しない場合には, アポプラスト経路の移動が行なわれている根拠と なる.このような方法で維管束細胞間の移動経路 を推定した例を次に紹介しょう ${ }^{(13)}$.

イネの葉身には縦に平行に走っている縦走維管 束がある.これらの維管束は，相互に細い横走維 管束によって連絡している. 図 5 は横走維管束断 面を電顕によって観察したものである，この維管 束は, 1 個の師管と 2 個の師部柔細胞および 1 個 の道管と 1 個の木部柔細胞から構成されていて, 維管束の中では最も単純な組織構成を示す。この 維管束周囲には維管束鞘細胞がないため, 各構成 細胞は葉肉細胞と接している. これら細胞間の原 形質連絡の頻度分布を調べた結果によれば，葉肉 細胞一師部柔細胞一木部柔細胞一葉肉細胞の各細胞 接触部にはいずれも原形質連絡が存在するが，師 管はいずれの細胞との間にも原形質連絡をもって いない.さらに，この師管は木部と師部の柔細胞 および葉肉細胞によって完全に包囲され, 師管の 壁が細胞間隙に露出することはない.このような 構造からスクロースの移動経路を推定すると, 葉 肉細胞から維管束柔細胞への移動は原形質連絡に よるシンプラスト移動が行なわれているが，その 過程でスクロースは師管周辺のアポプラストに放 出され, 最終的には師管の原形質膜を通して吸収 されているものと推定される.

維管束の周囲に維管束鞘細胞が存在する場合に は, スクロースはその直ぐ内側に配列する師部柔
細胞までシンプラスト経路で移動したのち，アポ プラストに放出される（図1）.

\section{師管・伴細胞複合体の構造と機能 ${ }^{(6)}$}

前記の横走維管束では, 師管が単独でアポプラ ストからスクロースを吸収すると考えられるが, 緹走維管束の師部では, 師管が伴細胞と呼ばれる 特定の細胞とだけ原形質連絡によって連絡し, こ の 1 対の師管と伴細胞がアポプラストからスクロ 一スを吸収している.師管と伴細胞はもともと 1 個の母細胞が 2 個に分裂して複合体を形成し，両 者は密接な相互依存関係をもっている.

師管と伴細胞の間の原形質連絡は，伴細胞側で 数本に枝分かれした分枝状原形質連絡で，このよ らな構造は普通の細胞間ではまったくみられな い. 師管・伴細胞複合体は通常, その周囲の柔細 胞との間に原形質連絡をもっていない。伴細胞に はクリステの発達したミトコンドリアが多量に存 在し，細胞基質の濃度が高い（図 6 ）。 また，師 管・伴細胞複合体の原形質膜には ATPase の存 在することが明らかになっている.

トウモロコシやテンサイの維管束細胞の浸透圧 を測定した結果によると，師管・伴細胞複合体 は, その周囲の師部柔細胞や葉肉細胞よりも浸透 圧が 2 倍以上も高くなっている(14). これらの測 定結果は, スクロースが単なる物理的拡散によっ て師部の細胞間を移動するのではなく，スクロー スが一旦アポプラストに放出されたのち，師管・ 伴細胞複合体によって積極的に吸収・濃縮されて いることを示している.ささらに，この吸収過程で は，伴細胞のミトコンドリアによって生産された ATP エネルギーが使われている.

原形質膜を通してアポプラストからスクロース が吸收される機構として，プロトンポンプ（sucrose-proton cotransport）が動いていると考えら れている.これによれば，スクロースは $\mathrm{H}^{+}$とと もに原形質膜上のキャリアーによってアポプラス トから師管・伴細胞複合体にとり込をれるが,

$\mathrm{H}^{+}$は ATP ェネルギーによってアポプラストの $\mathrm{K}^{+}$と置換される(5,10). 


\section{師部転送細胞の構造と機能 ${ }^{(7)}$}

マメ科植物葉身の網状脈の末端部に位置する細 い維管束には，師部転送細胞（phloem transfer cell）と呼ばれる特殊な構造の 細胞が存在する. 師部転送細胞では 細胞壁が 内部へ 突起状に 発達 し, 原形質膜の表面積が普通の細胞の 10 倍以上 にも拡大している（図 7). 寸なわち, 師部転送細 胞ではアポプラストに接する原形質膜の表面積が 大きいので，スクロースを吸収する㗢きが大き い.

師管に接する転送細胞はミトコンドリアを多く 含んでいて, 細胞基質の濃度が高いので, 伴細胞 に相当するものと考えられ，A型転送細胞と名つ けられている．師部転送細胞にはこの汪かにB型 もあるが，これは細胞壁突起が $\mathrm{A}$ 型転送細胞に接 する部分に限定され，その発達も比較的少なく， 細胞基質の濃度も低いので，普通の師部柔細胞に 相当すると考えられている.

師部転送細胞の細胞壁突起は，葉身が展開する 過程で気孔が完成し，葉肉組織の細胞間隙がで き，葉面積が完全展開時の $7 \sim 8$ 割に達した頃か ら発達し始める. 細胞壁突起の発達状態と光合成 産物の葉からの 流出との 関係をみた結果による と, 光合成産物の流出開始之同時に細胞壁突起の 形成が始まり，その後，突起の生長と並行して光 合成産物の流出速度も高まる。 また，暗所で育っ たエンドウの葉や，アルビノ突然変異体の葉で は，師部転送細胞の壁突起が正常の大きさと数に 達しない。これらの結果は, 師部転送細胞が光合 成産物の転流に密接に関与していることを証明す るものである。なお，師部転送細胞はマメ科植物 の特定の属に存在するもので，イネ科植物では見 つかっていない.

\section{師管の構造と転流仮説 ${ }^{(1,2,6)}$}

師管は普通の細胞と異なって特殊な構造をもっ ている，未成熟の師管細胞は，核と液胞およびミ トコンドリア，プラスチッドなどの小器官を含 み，普通の細胞と同じ構造であるが，成熟する過 程で細胞は細長い形となり，核と液胞が消失し，
新たに $\mathrm{P}$ ータンパクや特殊なプラスチッドがつく られる，P-タンパクは管状, 繊維状などの形状を 示し，師管内を移動したり分散してその形状が変 化する.また，師管内のプラスチッドにはデンプ ン粒を含むものとタンパク結晶体（図 8-上）を含 むものとがある．この活か，師管にはミトコンド リアと小胞体もみられる.

師管は師板によって仕切られているが，その師 板には直径 $0.1 \sim 15 \mu \mathrm{m}$ の 師孔が数多く存在す る.グルタールアルデヒドとオスミック酸を使っ た普通の固定法で電顕観察すると, 師孔周辺の細 胞壁にカロース（ $\beta-1,3-$ グルカン）が沈皘し，師 孔は塞がっている（図 8-上).これは恐らく，材 料を切断した際に急速にカロースが沈積して師孔 を塞ぎ，師管内容物が切り口から流出するのを防 いだものとみられる。

師管転流を説明する仮説の中で最もよく知られ ているのは Münch の圧流説である.この説によ れば，ソースの師管はスクロースを吸収して膨圧 が高まるが，シンクではスクロースが生長や呼吸 に使われたり貯蔵されるため，師管内のスクロー ス濃度が低下して膨圧も低下寸る。この膨圧差に よって師管汁液のソースからシンクへの流れが生 ずる．圧流説を支持する根拠のひとつとして，七 イヨウトネリコの師管滲出液の濃度を測定した実 験がある，これによると，葉が光合成産物を供給 している夏の間は，樹幹の上から下に向かって糖 濃度の勾配がみられる，その他，多くの根拠から 圧流説への支持は強いが，この説によれば，師管 汁液はソースとシンクの間を物理的障害なしに流 れなければならない。したがって，師管の中で最 も物理的障害の起こり易い師孔に $\mathrm{P}$ ータンパクな どの師管内容物が存在するか否かが圧流説を考兄 るらえで重要なポイントになる.

師孔の構造を生きたままの状態で正確にとらえ ることはきわめて困難である，それは，材料を切 断する際に師管にかかっている高い圧力が急激に 解放され，師管内の構造が破壊され易いためであ る.このような電顕観察の過程で生ずる影響をで きるだけ少なくするために，さまざまな工夫がな されている，たとえば，材料切断による影響を小 
さくするため，植物全体を液体窒素で瞬間的に凍 結させてから切断して固定する凍結置換法や，植 物を萎调させて師管内の膨圧が低下してから固定 する方法などが用いられている.

カボチャの植物体を 48 時間暗所に置いて, 師 管内容物が消費され，師管の膨圧が低下してから 固定し，電顕観察した結果によると，師孔には $\mathrm{P}$-タンパクがみられない、をた，筆者らも凍結置 換法によってイネの根と葉の師管を電顕観察し, 師孔が開いていて P-タンパクも存在しないこと を認めた (図 8一下). これらの観察結果は王流説 を支持する根拠となるが，一方では，師孔がカ口 ースで狭まっていたり，小胞体または $\mathrm{P}$ ータンパ クで師孔が塞っている例も報告されている.

また，葉柄や茥の一部を冷却したり、呼吸阻害 剂で処理すると、転流が阻害あるいは停止するこ となどから、師管転流は師部の代謝活性と結びつ いていることも示されている.このよらに, 圧流 説だけでは師管転流を十分に説明できないので, これを補足するものとしていくつかの能動転流 (active transport) 説が考えられている. 能動転 流説の主なものとしては, 電気浸透説, $\mathrm{P}$-タンパ クあるいは細胞質索条の運動説などがあるが，い ずれも十分に実証されたものではない。

\section{師管から貯蔵細胞への転流}

光合成産物は, 葉鞘, 茎, 根などの栄養器官に 蓄えられる場合と, 果実・種子などの生殖器官に 蓄えられる場合とがあり，このいずれの器官に蓄 えられるかによって転流経路も異なる。ここで は, イネ葉鞘の基本柔細胞に光合成産物が蓄えら れる場合の転流経路について述べることにしょう (図 1, 図 9) ${ }^{(12)}$.

イネの成熟した葉鞘の基部には一時的にデンプ ンが蓄積されるが，このデンプンは葉身でつくら れた光合成産物の一部が葉鞘維管束の師管から基 本柔細胞まで短距離転流してきたものである.こ の転流経路内には伴細胞, 師部柔細胞打よびメス トム鞘細胞などが存在する. 葉身の維管束と同じ ように，師管と伴細胞の間には原形質連絡があり， 両者は複合体を形成するが、この複合体とその周
囲の師部柔細胞との間には原形質連絡が存在しな い.したがって，師管内のスクロースは直接ある いは伴細胞を経由してアポプラストに放出される ものと考えられる，そして，アポプラスト内のス クロースは師部柔細胞によって吸収されたのち, 原形質連絡によってメストム鞘細胞から基本柔細 胞へと移動するものと考えられる.すなわち、ソ 一ス内の短距離転流経路とまったく逆の経路によ って移動することになるが，この場合に最も重要 な機能を果たすのは師部柔細胞である，葉鞘維管 束の師部柔細胞には比較的多数のミトコンドリア が含まれているので，この細胞がプロトンポンプ 機構によってスクロースを吸収, 濃縮しているも のと推定される. 一方, 基本柔細胞ではスクロ一 スからデンプンが合成されるため, 師部柔細胞か ら基本柔細胞へのスクロース濃度の勾配が生じ, シンプラスト経路の転流が行なわれるものと考え られる.

な拈，果実・種子内の転流についてはふれなか ったが，禾穀類ではスクロースが肧乳デンプン細 胞に入る段階で，原形質膜による吸収の行なわれ ていることが，最近の研究によって明らかにされ ていることをつけ加えて扣きたい。

\section{文献}

1）熊沢喜久雄: ‘光合成産物の 転流之蓄積”, 宮地重遠編, “光合成II", 朝倉書店, 1981, p. 174.

2） M. リチャードソン：“植物の物質輸送”，吉田邦久訳, 朝合書店, 1980.

3）長南信雄：農業技術，34，149（1979）.

4) W.M. Laetch : Ann. Rev. Plant Physiol., 25, 27 (1974).

5) R. T. Giaquinta: Ann. Rev. Plant Physiol., 34, 347 (1983).

6) J. Cronshaw : in "Dynamic Aspects of Plant Ultrastructure", ed. by A.W. Robards, McGraw-H1ll, 1974, p. 391.

7) B. E.S. Gunning \& J.S. Pate : in "Dynamıc Aspects of Plant Ultrastructure", ed. by A. W. Robards, McGraw-Hill, 1974, p. 441.

8) B. E.S. Gunning : in "Intercellular Communication in Plants : Studies on Plasmodesmata", ed. by B.E. S Gunning and A.W. Robards, 1976, p. 203.

9) C. B. Osmond \& F. A. Smith : in "Intercellular Communication in Plants : Studies on Plasmodesmata", ed. by B.E.S. Gunning and A.W. Robards, 1976, p. 229.

10) A. L. Kursanov: "Assimilate Transport in Plants", Elsevier, 1984. 
11）川原治之助，松田智明，長 南 信 雄 : 日作紀，49，330 (1980).

12）長南信雄，川原治之助，松田 智明：日作紀， 53，435 (1984).
13）長南信雄，川原治之助，松田智明：日作紀，54，160 (1985).

14) R.F.Evert, W. Eschrich \& W. Heyser : Planta, 138, 279 (1978).

プロィフル

石川 辰夫(Tatsuo Ishikawa) Vol 12, No.4, p. 252 参照, 現在東京大学応 用微生物研究所教授

伊奈 和夫(Kazuo Ina) Vol 20, No. 3, p. 148 参照

宇野 功(ISao Uno) Vol 20, No 12 , p. 777 参照

小野寺一清 (Kazukiyo Onodera) Vol 14, No.2, p. 93 参照, 現在東京大 学農学部助教授

神尾 好是 (Yoshiyuki Kamio) 昭 和 17 年 5 月 5 日 $<$ 略歴 $>$ 昭和 41 年東北大 学農学部農芸化学科卒業 $/ 47$ 年同大学大 学院農学研究科博士課程修了/同年朝日 麦酒(株)中央研究所勤務 ( 49年) $/ 52$ 年 信州大学医学部助教授, 現在にいたる. この間，49〜 51年米国カリフォルニア大 学バークレー校およびイリノイ大学アー バナ校研究員，58〜 59年ユニホームドサ 一ビス大学客員助教授く研究テーマと抱 負>分子生物学的手法により，ポリア ンの細胞表層膜における生物学的意義を 明らかにしてゆきたいく趣味>絵画，ジ ョギンク

熊谷 英彦(Hideh1ko Kumagai) 昭 和 15 年 10 月 30 日生 $<$ 略歴 $>$ 和昭 39 年京都 大学農学部農学科卒業 $/ 44$ 年同大学大学 院農学研究科博士課程修了, 同年同大学 食糧科学研究所助手 $/ 52$ 年同農学部食品 工学科助教授, 現在にいたるく研究テー マと抱負>微生物酵素による新しい生物 活性物質の合成. その活性物質の生理的 機能の解明などを行なってゆくことによ り，新しい微生物生産物の開発につなが ればと思いますく趣味>スポーツ（学生 とソフトボールや軟式野球をすること）

桑原 保正 (Yasumasa Kuwahara) Vol 16, No.7, p. 422 参照

越島 哲夫(Tetsuo Koshijima) Vol.
20, No.1， p. 12 参照

昆野 安彦(Yasuhiko Konno) 昭和 30 年 5 月 2 日生 $<$ 略歴 $>$ 昭和 54 年東京大 学農学部農業生物学科卒業/56年同大学 大学院農学系研究科修士課程修了/ 57 年 同博士課程中退／同年農林水産省農業技 術研究所農薬科研究員 $/ 58$ 年同省農業環 境技術研究所農薬動態科研究員, 現在に いたる. 60年農博く研究テーマと抱負〉 農業害虫の殺虫剤抵抗性機構の解明と抵 抗性打破剤の開発く趣味>山，トライア スロン

斎藤正三郎 (Shozaburo Saito) 昭和 6 年 5 月 22 日生 $<$ 略歴 $>$ 昭和 29 年東北大 学工学部応用化学科卒業 $/ 34$ 年同大学大 学院工学研究科博士課程修了(化学工学), 工博 $/ 37$ 年同工学部化学工学科助教授 $/$ 45年同教授, 現在にいたるく研究テーマ と抱負>魚油の超臨界カス抽出, 膜分離, 石炭の超臨界カス抽出, 高分子多成分系 のミクロ相分離構造 <趣味 $>$ 囲碁

柴岡 弘郎 (Hiroh Shibaoka) 昭和 9 年 1 月 21 日生<略歴>昭和 31 年東京大 学理学部生物学科卒業, 同年同大学大学 院進学 /36年同理学部付属植物園助手／ 44 年同理学部植物学教室助手 / 49 年東京 都立大学理学部助教授 $/ 56$ 年大阪大学理 学部教授，現在にいたるく研究テーマと 抱負>植物ホルモン，微小管，成長・分 化の三題話をできるだけ筋の通ったもの にすることく趣味＞歩くことと走ること

周 恒 㣚 (Zhōu Hénggāng) 1918 年生〈略歴＞ハルピソ原籍. 1953〜'72 年軽工業部食品局/'72 '84 年河北省廊 坊地区軽工業区副局長. 現在, 中国食品 協会理事，河北省食品学会長，河北省廊 地坊区食品研究所顧問，中国白酒協会名 誉会長. “白酒䁔製操作法” の制定を行な 、全国白酒の利酒大会を主催く研究テー マと抱負>茅台酒の研究，擃香型白酒の

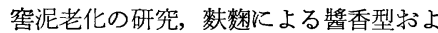
で濃香型白酒の製造，無蒸劣・生原料て
の白酒彆造の研究く趣味>古文学，スポ ーツ観賞，花を植えること

田村 五郎(Goro Tamura) Vol.11, No. 2, p. 136 参照

長南 信雄 (Nobuo Chonan) 昭和 7 年 12 月 15 日生 $<$ 略歴 $>$ 昭和 31 年東北大 学農学部農学科卒業／同年茨城県農業試 験場勤務／33年茨城大学農学部教務員／ 37 年東北大学農学部助手 $/ 47$ 年茨城大学 農学部助教授 (作物学), 現在にいたる <研究テーマと抱負 $>$ 作物諸器官の構造 之機能，とくに光合成産物の転流と蓄積 の問題を組織・細胞学的手法によって明 らかにしたいく趣味＞囲碁

原 素之 (Motoyuki Hara) 昭和 27 年 8 月 6 日生 <略歴 > 昭和 51 年東北大 学農学部水産学科卒業 $/ 53$ 年同大学大学 院農学研究科修士課程修了/同年水産打 東北区水産研究所研究員, 現在にいたる <研究テーマと抱負〉水産生物の遺伝. 育種, 野生海産種の育種による生産管理 く趣味〉スキー，ゴルフ

藤井 弘志 (Hiroshi Fuj11) 昭和31 年 12 月 21 日生 $<$ 略歴 $>$ 昭和 54 年岩手大学 農学部農芸化学科卒業／同年山形県立農 業試験場化学部研究員, 現 在にいたる <研究テーマと抱負〉水稲，大豆の多収 技術に関する研究(栄盖生理的). 今後は 植物と土靯 (地力窒素の動態) を関連づ けた方向で研究してゆきたいく趣味〉ス ポーツ（野球，テニスなど）

村田 道雄 (Michio Murata) 昭和 33年 10 月 5 日生<略歴>1981年東北大学 農学部食糧化学科卒業. 同大学大学院修 士課程修了後, サントリ一生物有機科学 研究所勤務, 現在東北大学農学部助手 <研究テーマと抱負〉渦鞭毛藻の産生す る生物活性物質. 微量生体情報物質を見 つけたいく趣味＞お酒を飲もこと 